\title{
Simulation tests on air flow through selected types of throttle bodies
}

\begin{abstract}
The paper presents selected simulation test results of the air flow through various types of throttle bodies. The experimental tests were mapped in virtual conditions, using the experimental conditions as initial and edge conditions. The geometry was implemented from the Solid Works software into the COSMOS-FloWorks, in which the simulations were carried out. The results represented supplementation to test stand investigations. The comparison of classic, two stage and profiled intake throttles provided answers to the ques-tions related to the necessity to differentiate the structure in order to achieve specific flow characteristics.
\end{abstract}

Key words: combustion engine, fuel delivery system, throttle body, simulation

\section{Badania symulacyjne przeplywu powietrza przez wybrane typy przepustnic}

W artykule przedstawiono wybrane wyniki badań symulacyjnych procesu przeptywu powietrza przez różne typy przepustnic. W warunkach wirtualnych odwzorowywano badania doświadczalne, wykorzystując jako warunki brzegowe $i$ poczatkowe warunki eksperymentalne. Geometrię zaimplementowano z programu Solid Works do COSMOSFloWorks, w którym przeprowadzono symulacje. Wyniki badań stanowity uzupetnienie badań stanowiskowych, gdzie dokonywano jedynie oceny ilościowej, bez jakościowej analizy procesów. Porównanie przepustnicy klasycznej, dwuprzelotowej i z profilowanym wlotem dało odpowiedzi na pytania zwiąane z koniecznościa zróżnicowania budowy celem osiagnięcia określonych cech przeplywowych.

Słowa kluczowe: silnik spalinowy, układ zasilania, podzespót przepustnicy, symulacja

\section{Introduction}

The basic equations used for the mathematical description of the flow phenomena related to possibly most general model of fluid (for 3D space) and based on three main principles of mechanics are as follows:

- for the principle of mass conservation (the continuity equation):

$$
\frac{\partial \rho}{\partial t}+\operatorname{div}(\rho u)=0
$$

- for the principle of momentum and angular momentum conservation:

$$
\rho \frac{\partial \mathrm{u}}{\partial \mathrm{t}}=\rho \mathrm{F}+\operatorname{div} \mathrm{S}
$$

- for the principle of energy conservation

$$
\begin{aligned}
& \rho \frac{\mathrm{d}}{\mathrm{dt}}\left(\mathrm{TC}_{\mathrm{v}}+\frac{\mathrm{u}^{2}}{2}\right)= \\
& =\rho \mathrm{Fu}+\rho \mathrm{q}+\operatorname{div}(\operatorname{\Gamma grad} \mathrm{T})+\operatorname{div}(\mathrm{Su})
\end{aligned}
$$

of which: $\mathrm{t}$ - time, $\mathrm{u}$ - fluid velocity, $\rho$ - fluid density, $\mathrm{F}$ body force for mass unit, $\mathrm{S}-$ stress tensor, $\mathrm{C}_{\mathrm{v}}-$ specific heat capacity with fixed volume, $\mathrm{T}$ - temperature, $\mathrm{q}$ - unit output of internal source of heat, $\Gamma$ - thermal conductivity.

The unique solution of the above equations, enabling in consequence determination of pressure variation course in the engine intake system, is possible in very few cases only and with numerous simplifying assumptions. Heat exchange (particularly penetration) at the medium flow brings about

\section{Wstęp}

Podstawowymi równaniami służącymi do matematycznego opisu zjawisk przepływu w odniesieniu do możliwie ogólnego modelu płynu (dla trójwymiarowej przestrzeni) i w oparciu o trzy główne zasady mechaniki są równania:

- dla zasady zachowania masy (równanie ciągłości) - równanie (1),

- dla zasady zachowania pędu i momentu pędu (2),

- dla zasady zachowania energii (3),

gdzie: $\mathrm{t}$ - czas, u - prędkość płynu, $\rho$ - gęstość płynu, $\mathrm{F}$ - siła masowa dla jednostki masy, $\mathrm{S}$ - tensor naprężeń, $\mathrm{C}_{\mathrm{v}}$ - ciepło właściwe przy stałej objętości, $\mathrm{T}$ - temperatura, q - wydajność jednostkowa wewnętrznego źródła ciepła, $\Gamma$ - przewodność cieplna.

Jednoznaczne rozwiązanie powyższych równań, dające w efekcie możliwość np. wyznaczenia przebiegu zmian ciśnienia w układzie dolotowym silnika jest możliwe jedynie w bardzo nielicznych przypadkach, przy wielu założeniach upraszczających. Wiele problemów nastręcza wymiana ciepła (szczególnie wnikanie) przy przepływie czynnika i bardzo często jest przez badaczy pomijana. Uzyskane rozwiązania ważne są jedynie w granicach poczynionych założeń i najczęściej wykazują odchylenia od rezultatów otrzymanych doświadczalnie w warunkach rzeczywistych.

Obecnie na rynku oprogramowania znajduje się bogata oferta programów do analizy inżynierskiej z zakresu numerycznej mechaniki płynów (CFD). Są to m.in. programy: ANSYS, COSMOSFloWorks, FLUENT, PATRAN/ NASTRAN, KIVA [4]. Programy oferują podobny zakres 
a lot of problems and is frequently ignored by the researchers. The solutions obtained are valid within the limits of assumptions only and mostly show deviations from the results obtained experimentally under real conditions.

The software market offers a wide range of engineering analysis programs in the scope of Computational Fluid Dynamics (CFD). These include: ANSYS, COSMOSFloWorks, FLUENT, PATRAN/NASTRAN, KIVA [4]. The programs offer similar range of tools and options. They are used for the analysis of flow of fluids and gases and heat exchange processes. They are capable of analyzing numerous problems concerning flow processes with the use of wide range of fluid definitions and self defining options. They make it possible to analyze external, internal, stationary, non-stationary, turbulent, laminar flows, flows of viscous, non-viscous, Newtonian, non-Newtonian, compressible, non-compressible, multi-phase and other fluids. Such programs can be used in practically any field of industry and in theoretical considerations on fluid mechanics phenomena as well as in research work.

Another group of specialist computational packages that can be used in a specific field, particularly the automotive sector, includes: AVL BOOST and FIRE, FLUENT with the modules: GT Turbo, Mixsim, Polyflow; WAVE and VECTICS from Ricardo.

One should remember, however, that the full mapping of reality in the simulation models is impossible. The final verification of the intake system elements should always be carried out during experimental research on an engine furnished with prototype solutions. The simulation tests may only complement the experiments where the correctness of the variant assumed may be subject to conclusions or preliminary analysis may be carried out. narzędzi i możliwości. Służą do analizy przepływów cieczy i gazów oraz procesów wymiany ciepła. Mają możliwość analizy wielu problemów dotyczących procesu przepływu z wykorzystaniem szerokiego zasobu definicji płynów oraz możliwości samodzielnego definiowania. Umożliwiają analizę przepływów zewnętrznych, wewnętrznych, stacjonarnych, niestacjonarnych, turbulentnych, laminarnych, przepływów płynów lepkich, nielepkich, newtonowskich, nienewtonowskich, ściśliwych, nieściśliwych, wielofazowych i innych. Programy te można wykorzystać praktycznie w każdej dziedzinie przemysłu, jak również w rozważaniach teoretycznych na temat zjawisk mechaniki płynów i w pracach badawczych.

Do innej grupy specjalistycznych pakietów obliczeniowych, które można wykorzystać w konkretnej dziedzinie, a dokładnie w motoryzacji, można zaliczyć m.in. AVL BOOST i FIRE, FLUENT z modułami: GT Turbo, Mixsim, Polyflow; WAVE i VECTICS firmy Ricardo.

Należy jednak pamiętać, że pełne odwzorowanie rzeczywistości w modelach symulacyjnych nie jest możliwe. Ostateczna weryfikacja elementów układu dolotowego zawsze powinna być przeprowadzana $\mathrm{w}$ toku badań doświadczalnych na silniku wyposażonym w prototypowe rozwiązania. Badania symulacyjne mogą stanowić uzupełnienie badań doświadczalnych, gdzie można wnioskować o poprawności przyjętego wariantu konstrukcyjnego lub dokonać wstępnej analizy.

\section{Przedmiot badań}

Przedmiotem badań były trzy różniące się konstrukcyjnie przepustnice, których opis techniczny i zastosowanie przedstawiono w pracy [5]. Podstawowe wymiary zestawiono na rys 1 . a)

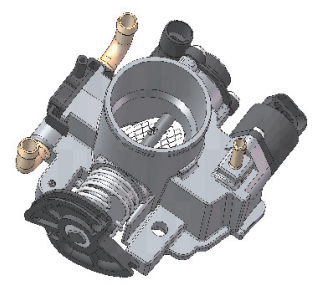

intake diameter - $46 \mathrm{~mm}$, flap thickness $-2 \mathrm{~mm}$, flap axle diameter $-9.5 \mathrm{~mm}$

średnica wlotu - $46 \mathrm{~mm}$, grubość listka $-2 \mathrm{~mm}$, średnica osi listka $-9,5 \mathrm{~mm}$ b)

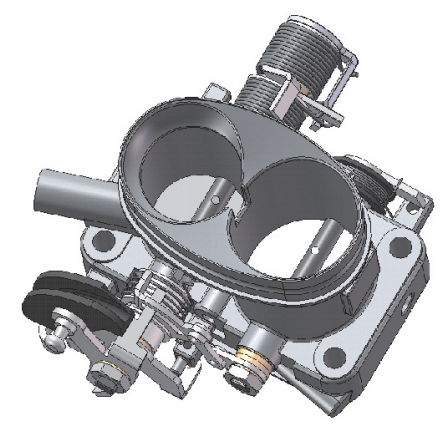

intake diameter: stage I - $15 \mathrm{~mm}$, stage II - 44 $\mathrm{mm}$, flap thickness: stage I $-1.5 \mathrm{~mm}$, stage II $-1.5 \mathrm{~mm}$, flap axle diameter: stage $\mathrm{I}-8 \mathrm{~mm}$, stage II $-8 \mathrm{~mm}$

średnica wlotu: I stopień - 15 mm, II stopień $44 \mathrm{~mm}$, grubość listka: I stopień - 1,5 mm, II stopień - 1,5 mm, średnica osi listka:

I stopień $-8 \mathrm{~mm}$, II stopień $-8 \mathrm{~mm}$ c)

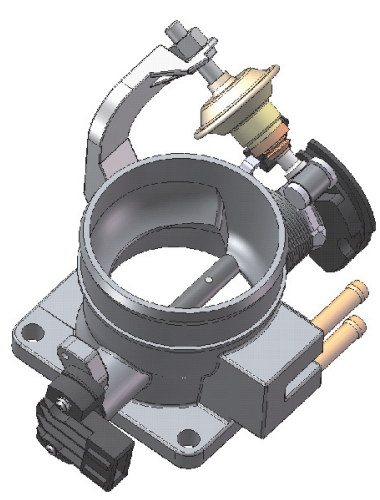

intake diameter - $64 \mathrm{~mm}$, flap thickness $-2 \mathrm{~mm}$, flap axle thickness $-10 \mathrm{~mm}$

średnica wlotu - $64 \mathrm{~mm}$, grubość listka $-2 \mathrm{~mm}$, średnica osi listka $-10 \mathrm{~mm}$

Fig. 1. Throttle bodies investigated: $\mathrm{a}$ - classic, $\mathrm{b}-$ two-stage, $\mathrm{c}-$ with a profiled intake

Rys. 1. Badane przepustnice: $a-k l a s y c z n a, b-d w u s t o p n i o w a, c-z$ profilowanym wlotem 


\section{The object of the investigations}

The object of the investigation were throttle bodies differing in structure, the technical description and their applications are presented in paper [5]. Their basic dimensions are listed in Fig. 1.

\section{The methodology of the investigations}

The calculations carried out in the COSMOSFloWorks environment, with the computational algorithm based on Navier-Stokes equations, where the solution is obtained numerically with the use of the MES. The equations are supplemented by equation of state of fluid describing its nature and by the empirical dependencies of fluid viscosity and thermal conductivity on temperature. The topic is ultimately made precise by introduction of geometry, edge conditions and initial conditions for the case investigated.

The investigations consisted in simulating the air flow through a model throttle body, mapping the geometry of a real investigated object that was created in the Solid Works. Similar ambient conditions and initial conditions correspond to tests of throttle bodies carried out on a real test stand specially built for this purpose as presented in paper [5]. The experimentally obtained pressure variation courses in the measuring tank were used as edge values of the flow simulation. The simulations were carried out for three flap positions (minimum, 50\% and full opening) with the by-pass valve in fully open.

In addition to the analysis in the form of color range in the flow area, reflecting the variability of particular parameters, we may also obtain results in the form of diagrams related to a selected point. This can also be settled in a global layout for the whole computational space, in local layout on one of the object's surfaces or in a defined volume of the object (Fig. 2).

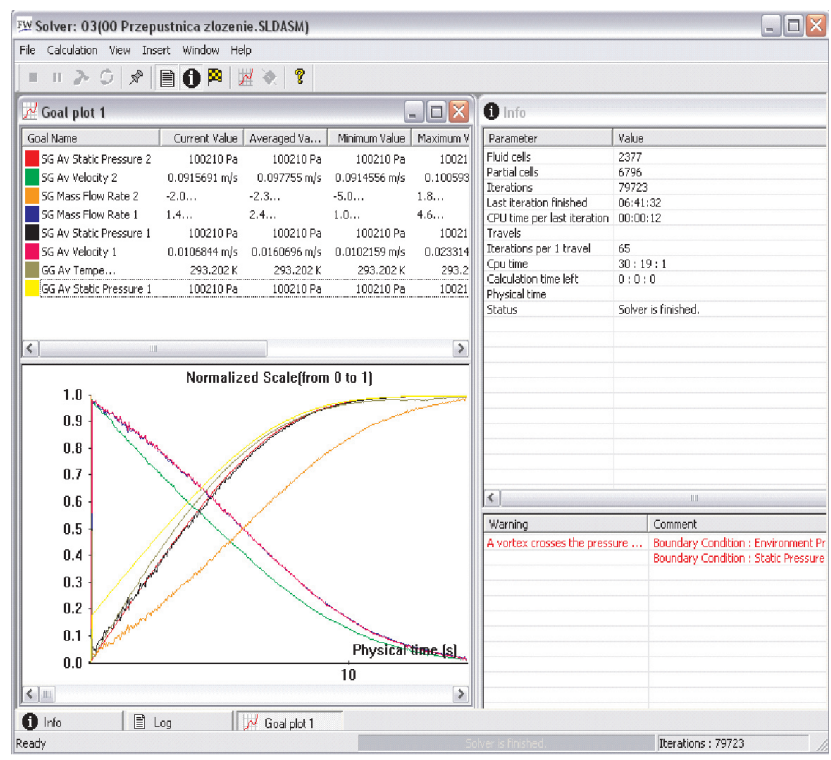

Fig. 2. View of panel from the result presentation option in the form of diagrams

Rys. 2. Widok panelu z możliwościa prezentacji wyników w postaci wykresów

\section{Metodyka badań}

Obliczenia przepływowe przeprowadzono w środowisku COSMOSFloWorks, gdzie algorytm obliczeniowy opiera się na równaniach Naviera-Stokesa, przy czym rozwiązanie otrzymuje się na drodze numerycznej, wykorzystując MES. Równania te uzupełnione sa o równanie stanu płynu opisujące jego naturę oraz o empiryczne zależności lepkości płynu i przewodności cieplnej od temperatury. Zagadnienie jest ostatecznie precyzowane przez wprowadzenie geometrii, warunków brzegowych oraz warunków początkowych dla badanego przypadku.

Badania polegały na zasymulowaniu przepływu powietrza przez model przepustnicy, odwzorowujący geometrię rzeczywistego obiektu badanego, który stworzono w Solid Works. Podobnie warunki otoczenia oraz początkowe odpowiadają badaniu na rzeczywistym specjalnie do tego celu zbudowanym stanowisku do badań przepustnic przedstawionym w publikacji [5]. Jako wartości brzegowe symulacji przepływu wykorzystano otrzymane doświadczalnie przebiegi zmian ciśnienia w zbiorniku pomiarowym. Symulacje przeprowadzono dla trzech położeń listka przepustnicy (minimalne, 50\% i pełne otwarcie) przy otwartym zaworze obejściowym.

Poza analizą w postaci palety barw w obszarze przepływu, obrazujących zmienność poszczególnych parametrów, można również otrzymać wyniki w postaci wykresów w odniesieniu do wybranego punktu. Można ustalić to w układzie globalnym dla całej przestrzeni obliczeniowej, w układzie lokalnym na jednej z powierzchni obiektu lub w określonej objętości obiektu (rys. 2).

\section{Wyniki badań i ich analiza}

W badaniach symulacyjnych starano się odwzorować badania eksperymentalne przeprowadzone na stanowisku [5], dlatego warunki początkowe i brzegowe (rys. 3) odpowiadały badaniom stanowiskowym, a geometria przepływu była implementowana ze środowiska Solid Works.

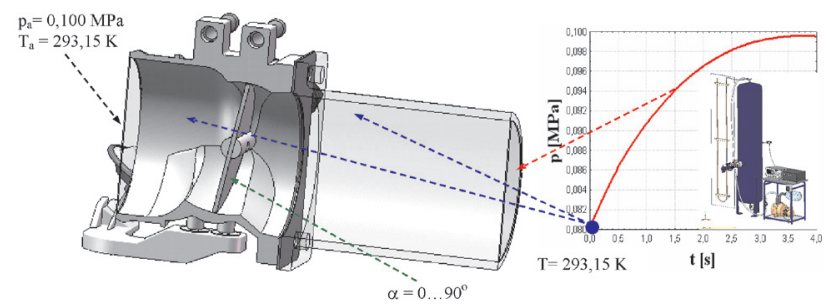

Fig. 3. Edge conditions and initial conditions

Rys. 3. Warunki brzegowe i poczatkowe

Właściwości płynu zdefiniowano jako powietrze $\mathrm{w}$ warunkach normalnych. Z uwagi na to, że badania miały charakter dynamiczny, najlepszą formą analizy byłoby zaprezentowanie wyników w formie filmu $\mathrm{z}$ całego procesu, niestety w artykule zaprezentowane będą jedynie obrazy w określonym odstępie czasowym od początku symulacji.

Z uwagi na obszerność wyników, w dalszej części artykułu zaprezentowano jedynie wyniki zawierające wybrane stopnie uchylenia przepustnicy w określonym punkcie czasowym. 


\section{Results and their analysis}

The simulation investigations were an attempt to map the experimental research carried out on the test stand [5], therefore the initial and edge conditions (Fig. 3) corresponded to the test stand investigations and the flow geometry was implemented from the Solid Works environment.

The fluid properties were defined as air under normal conditions. Due to the fact that the investigations were of dynamic nature, the best form of analysis would be to present the results as a film of the whole process, unfortunately, the paper will only present pictures in a defined time interval from the beginning of the simulation.
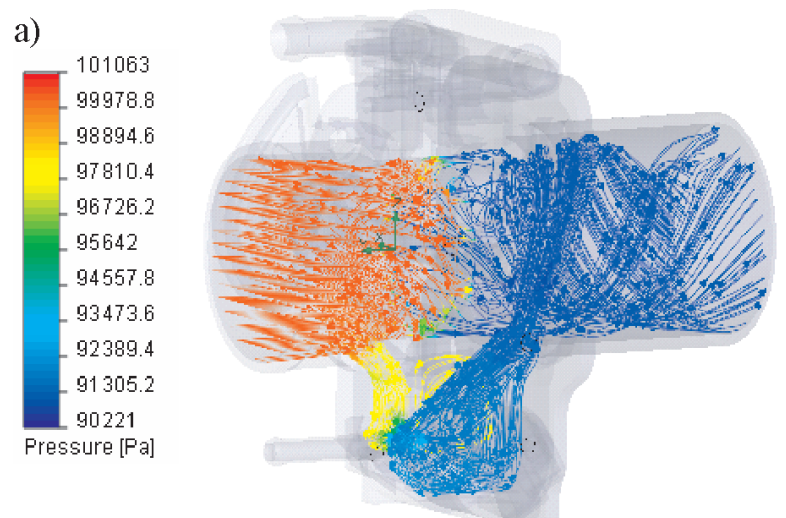

c)
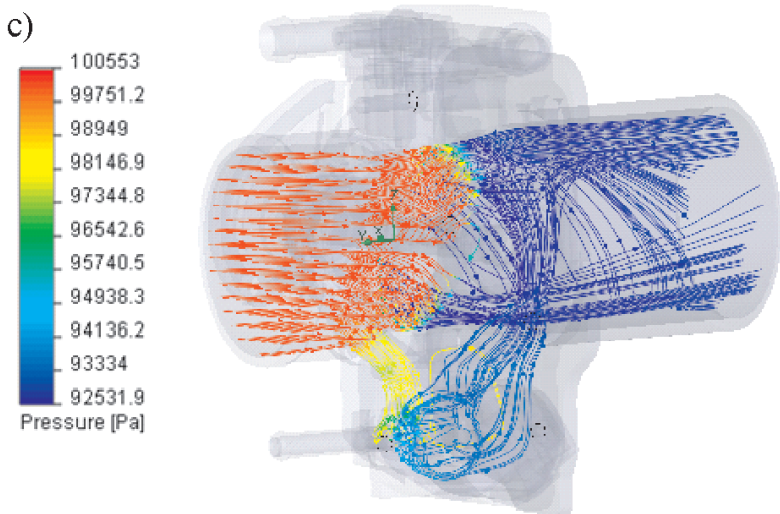

e)
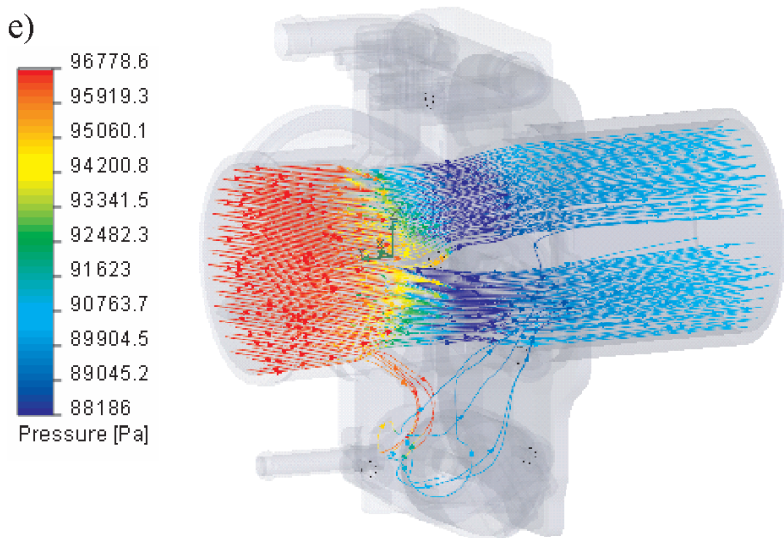

\section{Przepustnica klasyczna}

W przypadku zamkniętej przepustnicy przepływ jest silnie zdławiony (rys. 4a i b), część powietrza przepływa przez główny przelot na skutek występujących nieszczelności, natomiast przepływ w głównej mierze odbywa się z wykorzystaniem kanału obejściowego. Przepustowość kanału obejściowego jest na tyle niewielka, iż ciśnienie panujące przed przepustnicą ma wartość ciśnienia atmosferycznego, natomiast ciśnienie za przepustnicą odpowiada wartości ciśnienia zadanego, jako warunek brzegowy (wynik pomiaru na stanowisku). Powietrze w kanale obejściowym uzyskuje największą prędkość, powyżej $10 \mathrm{~m} / \mathrm{s}$, jednak maksymalne prędkości występujące w tym obszarze miejscowo są o

b)
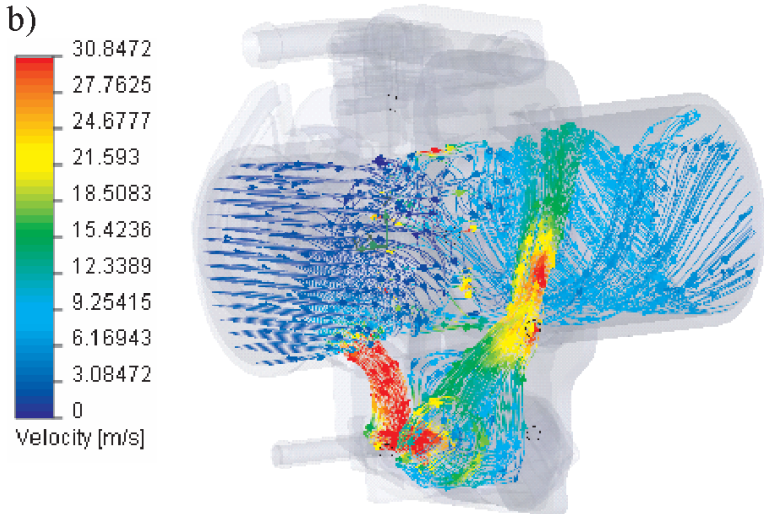

d)
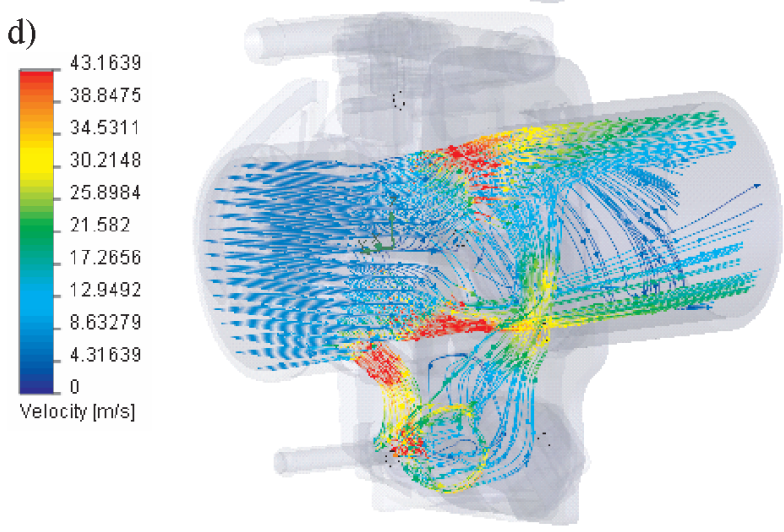

f)
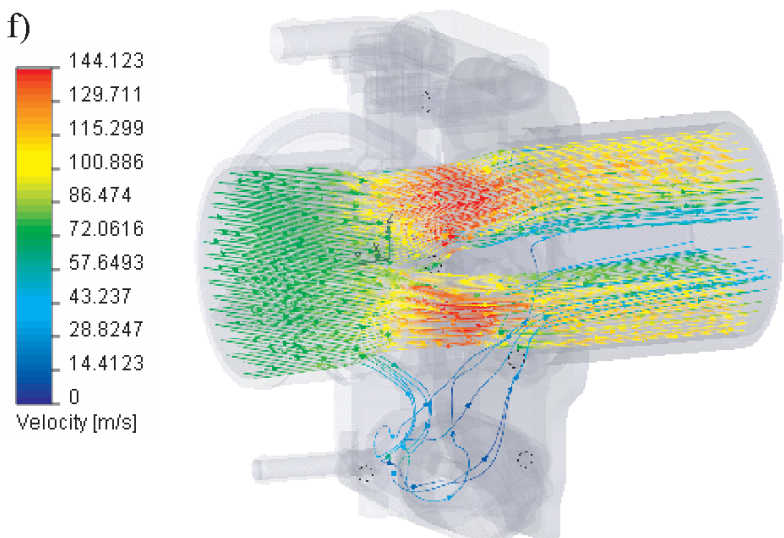

Fig. 4. Visualization of flow through the classic throttle body: $\mathrm{a}, \mathrm{c}, \mathrm{e}-$ pressure variations, $\mathrm{b}, \mathrm{d}, \mathrm{f}-\mathrm{flow}$ velocities; $\mathrm{a}$ and $\mathrm{b}-\alpha=3^{\circ}, \mathrm{t}=3.4 \mathrm{~s}$; $\mathrm{c}$ and $\mathrm{d}-\alpha=20^{\circ}, \mathrm{t}=1.59 \mathrm{~s} ; \mathrm{e}$ and $\mathrm{f}-\alpha=90^{\circ}, \mathrm{t}=0.14 \mathrm{~s}$

Rys. 4. Wizualizacja przeplywu przez przepustnicę klasyczną: $a, c, e-z m i a n y ~ c i s ́ n i e n i a, ~ b, d, f-$ prędkości przeplywu; $a$ i $b-\alpha=3^{\circ}, t=3,4$; c i $d-\alpha=20^{\circ}, t=1,59 \mathrm{~s}$; e if $-\alpha=90^{\circ}, t=0,14 \mathrm{~s}$ 
Considering the plentitude of results, only those containing selected throttle body opening grades in a defined point of time are presented further herein.

\section{Classic throttle body}

With the throttle body closed, the flow is strongly throttled (Fig. 4a and b), some air flows through the main passage as a result of occurring leakages, whereas the flow mainly takes place through the by-pass. The by-pass throughput is so low that the pressure before the throttle body has the atmospheric pressure value, while the pressure after the throttle body corresponds to the pressure set as the edge condition (test stand measuring result). The air in the by-pass obtains the highest velocity above $10 \mathrm{~m} / \mathrm{s}$, however, the maximum velocities occurring in this area are locally much higher and reach supersonic velocities. The air flowing out of the by-pass causes swirling of the whole flow and increase of its mean velocity at the outlet, which may improve the formation of the combustible mixture with scarce mass expenditure and local flow disturbances.

Opening the throttle body by $20^{\circ}$ (Fig. $4 \mathrm{c}$ and d) causes increase of throughput; at the current line analysis the flow concentration around the throttle body flap wherever the flow surface increased is visible. The valve share decreases, which results in decreased swirl of the stream in the passage. We observe a significant growth of the mean flow velocity in relation to the closed throttle body, while the difference of the mean value at intake and outlet was reduced to $6.5 \mathrm{~m} / \mathrm{s}$.

With the throttle body fully open (Fig. 4e and f) the flow in the by-pass shall vanish. The flow is throttled by the lateral throttle body and flap axle surface, which causes bifurcation of the stream. The highest flow velocity (ca. $130 \mathrm{~m} / \mathrm{s}$ ) occurs in the throat and is high enough to cause the drop of pressure at the intake down to $95 \mathrm{kPa}$.

\section{Two-stage throttle body}

For the position $\alpha=10^{\circ}$ (Fig. 5a and b) the flow is carried out through the surface of the first passage and leakages of the second. The static pressure distribution is of similar nature to that of the classic throttle body. The simulation showed that opening the throttle body to the position $10 \mathrm{o}$ causes vanishing of the flow in the by-pass. The large swirl of the air stream results from the occurrence of leakages in the second passage. The flow in the first passage has a mild course and the trajectories of air current lines are determined by the model geometry.

Opening the throttle body of the first passage to the position $\alpha=60^{\circ}$ (Fig. 5c and d) causes partial opening of the second throttle valve. It results in the increase of the air mass flowing through the object investigated. This reduces the stream swirl.

When both throttle bodies are open, the global pressure in the whole object is reduced, the varied distribution is visible on the cross-section plane (Fig. 5e and f). The pressure significantly drops in the cross-section throat and after the flap axle, to reach the value of ca. $90 \mathrm{kPa}$. Upon the experimental investigations, it appeared that the impact of throttle body and flap axle on the throughput is scarce for large openings, while the simulation investigations showed wiele większe i dochodzą do prędkości ponaddźwiękowych. Powietrze, wydostając się z kanału obejściowego powoduje zawirowanie całego przepływu i zwiększenie jego średniej prędkości na wylocie, co przy niewielkim wydatku masowym może korzystnie wpływać na tworzenie mieszaniny palnej, przy lokalnych zakłóceniach przepływu.

Otwarcie przepustnicy o $20^{\circ}$ (rys. 4c i d) powoduje zwiększenie przepustowości; przy analizie linii prądu widoczna jest koncentracja przepływu wokół listka przepustnicy, gdzie nastąpiło zwiększenie powierzchni przepływu. Udział zaworu zmniejsza się, co skutkuje mniejszym zawirowaniem strugi w przelocie. Obserwujemy znaczny wzrost średniej prędkości przepływu w stosunku do przepustnicy zamkniętej, natomiast różnica średniej wartością prędkości na wlocie i wylocie zmniejszyła się do $6,5 \mathrm{~m} / \mathrm{s}$.

Przy pełnym otwarciu przepustnicy (rys. 4e i f) zanika przepływ w zaworze obejściowym. Przepływ dławiony jest jedynie przez powierzchnię boczną przepustnicy i powierzchnię osi listka, co powoduje rozwidlenie strugi. Największa prędkość przepływu (ok. $130 \mathrm{~m} / \mathrm{s}$ ) występuje w przewężeniu i jest na tyle duża, że wartość ciśnienia na wlocie spadła do wartości $95 \mathrm{kPa}$.

\section{Przepustnica dwustopniowa}

Dla położenia $\alpha=10^{\circ}$ (rys. 5a i b) przepływ odbywa się przez powierzchnię pierwszego przelotu oraz nieszczelności drugiego. Rozkład ciśnienia statycznego ma podobny charakter jak dla przepustnicy klasycznej. Symulacja wykazała, iż otwarcie przepustnicy do położenia $10^{\circ}$ powoduje zanik przepływu w kanale obejściowym. Znaczne zawirowanie strugi powietrza wynika $\mathrm{z}$ występowania nieszczelności przelotu drugiego. Przepływ w przelocie pierwszym ma łagodny przebieg, a trajektorie linii prądu powietrza zdeterminowane są geometrią modelu.

Otwarcie przepustnicy pierwszego przelotu do położenia $\alpha=60^{\circ}$ (rys. $5 \mathrm{c} \mathrm{i} \mathrm{d)} \mathrm{powoduje} \mathrm{częściowe} \mathrm{otwarcie} \mathrm{drugiej}$ przepustnicy. Skutkuje to zwiększeniem masy powietrza przepływającego przez badany obiekt. Zmniejsza się zawirowanie strugi.

Gdy otwarte są obydwie przepustnice, ciśnienie globalne w całym obiekcie ulega obniżeniu, zróżnicowany rozkład widoczny jest na płaszczyźnie przekroju (rys. 5e i f). Ciśnienie wyraźnie obniża się na przewężeniu przekroju i za osią listka przepustnicy, by osiągnąć wartość około $90 \mathrm{kPa}$. Z badań doświadczalnych okazało się, że wpływ przepustnicy i osi listka na przepustowość jest niewielki dla dużych otwarć, natomiast z badań symulacyjnych, że ma znaczący wpływ na miejscowy rozkład ciśnienia i prędkości przepływu.

\section{Przepustnica z profilowanym wlotem}

Profilowany wlot uniemożliwia przepływ powietrza przez jedną z połówek powierzchni przepływu, jakie występują w przepustnicy z przelotem stałym, co pozwala wnioskować o tym, iż profilowanie może zastąpić podwójny przelot, który jest konstrukcyjnie kłopotliwy w wykonaniu. Powoduje to zmniejszenie przepustowości przepustnicy w zakresie małych otwarć i poprawia płynność regulacji masy powietrza. Korpus nie jest wyposażony w zawór obejściowy, a regulacja masy powietrza odbywa się za pomocą zmiany położenia przepust- 
a)

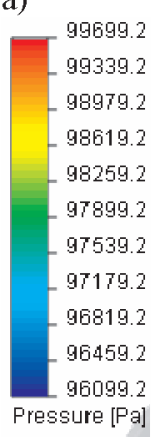

c)

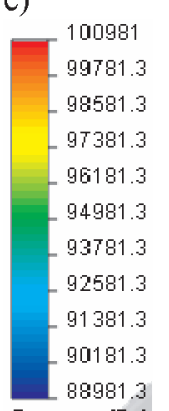
Pressure [Fa]

e)

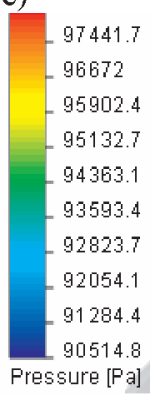

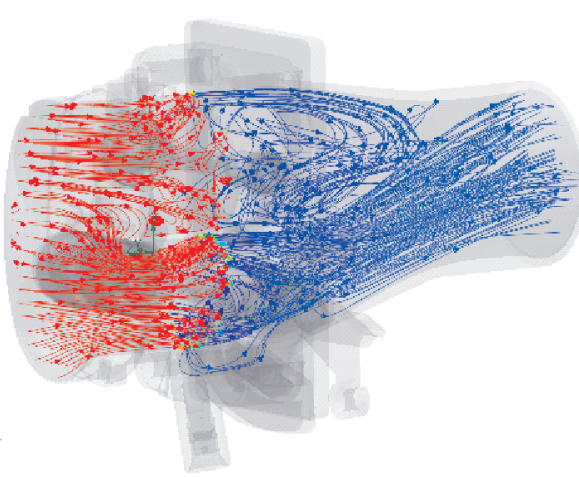
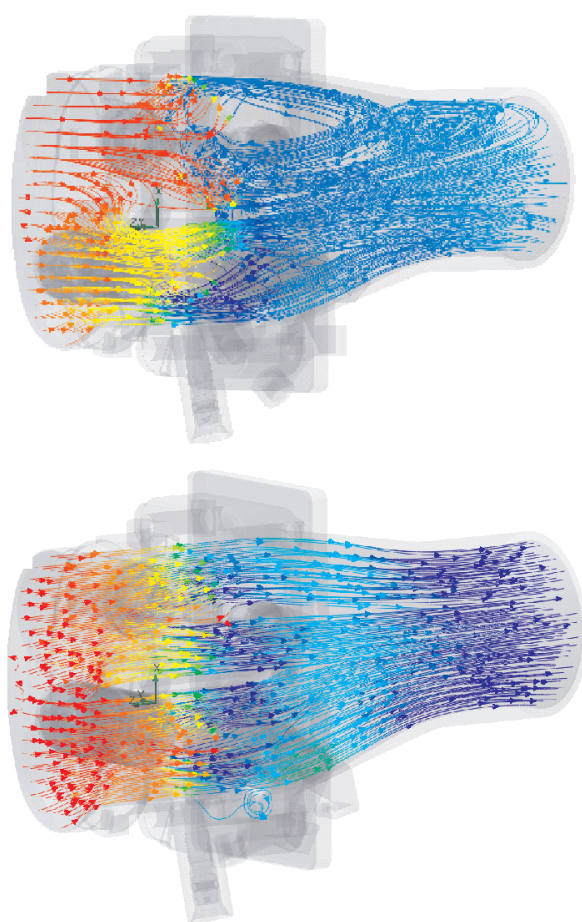

b)

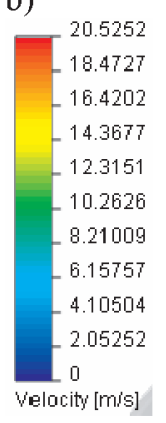

d)

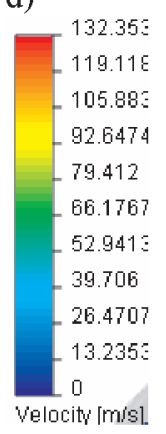

f)

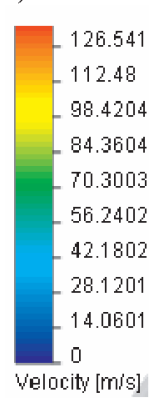

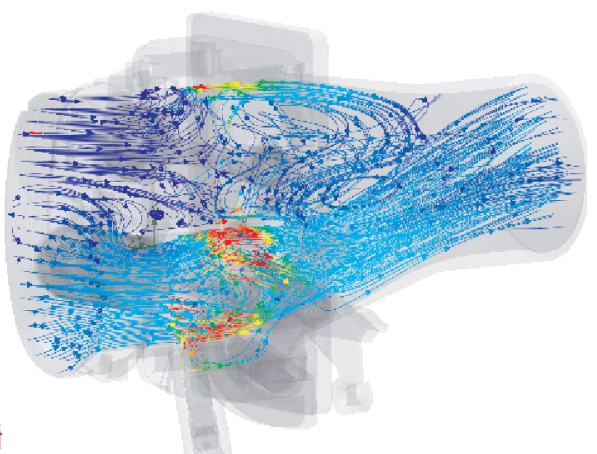
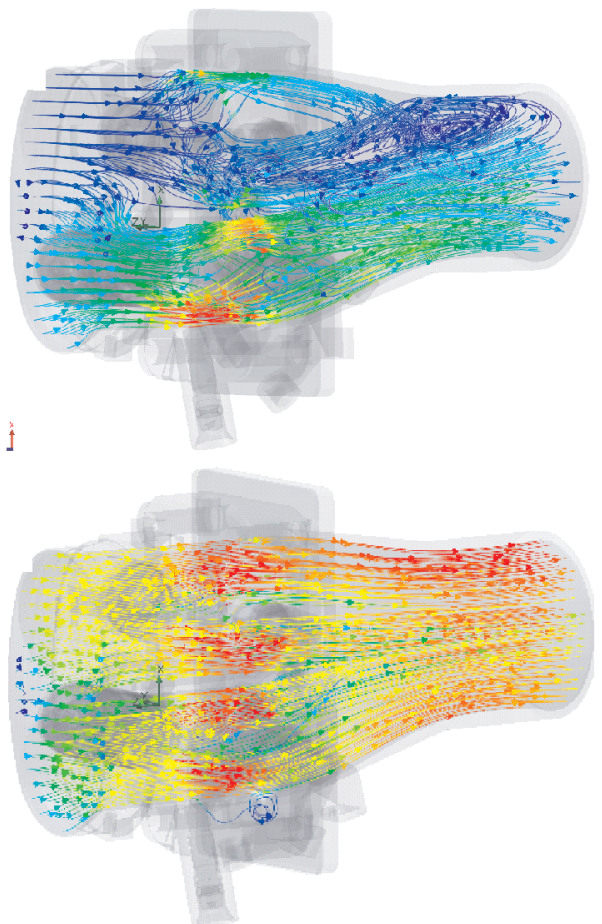

Fig. 5. The visualization of the flow through the two-stage throttle body: $\mathrm{a}, \mathrm{c}, \mathrm{e}-$ pressure variations, $\mathrm{b}, \mathrm{d}, \mathrm{f}-\mathrm{flow}$ velocities; $\mathrm{a}$ and $\mathrm{b}-\alpha=10^{\circ}$,

$$
\mathrm{t}=3.4 \mathrm{~s} ; \mathrm{c} \text { and } \mathrm{d}-\alpha=60^{\circ}, \mathrm{t}=1.59 \mathrm{~s} ; \mathrm{e} \text { and } \mathrm{f}-\alpha=90^{\circ}, \mathrm{t}=0.14 \mathrm{~s}
$$

Rys. 5. Wizualizacja przeplywu przez przepustnice dwustopniową: $a, c$, e-zmiany ciśnienia, $b, d$, $f$-prędkości przeplywu; a i $b-\alpha=10^{\circ}$,

$t=3,4 \mathrm{~s} ;$ c id $-\alpha=60^{\circ}, t=1,59 \mathrm{~s} ;$ e if $-\alpha=90^{\circ}, t=0,14 \mathrm{~s}$

that it has a large impact on the local pressure and flow velocity distribution.

\section{Throttle body with profiled intake}

The profiled intake prevents the air flow through one of the flow surface halves that occur in the throttle body with fixed passage, which suggests that the profiling may replace double passage that is structurally difficult to make. It causes the reduction of the throttle body throughput for small openings and improves the liquidity of air mass adjustment. The body has no by-pass valve and the air mass adjustment is carried out by means of changing the throttle body position (throttle positioner). Compared to the model flow simulation through classic throttle body with by-pass, (Fig. 4), the flow is accompanied by significantly lower swirl. Most of the air stream (Fig. 6a and b) flows on the opposite site of the profiling, which causes a slight air swirl under the throttle flap. nicy (nastawnik przepustnicy). W porównaniu z symulacją przepływu przez przepustnicę klasyczną z kanałem obejściowym (rys. 4) przepływowi towarzyszy znacznie mniejsze zawirowanie. Większość strugi powietrza (rys. 6a i b) przepływa po przeciwnej stronie profilowania, co powoduje niewielkie zawirowanie powietrza pod listkiem przepustnicy.

Dla otwarcia przepustnicy $\alpha=40^{\circ}$ (rys. 6c i d) odsłonięta jest już dolna szczelina przepływu. Mimo to przepływ nadal w głównej mierze przebiega przez górną powierzchnię po przeciwnej stronie profilowania. Przepływ, podobnie jak w poprzednim przypadku, ma niewielki stopień zawirowania strugi powietrza.

Wpływ występowania profilowania zanika w momencie pełnego otwarcia przepustnicy (rys. 6e i f). Linie prądu są prawie równoległe. Występuje w tym przypadku największy wydatek masowy rzędu $0,85 \mathrm{~kg} / \mathrm{s}$, co wiąże się z największą średnicą przelotu spośród wszystkich badanych przepustnic. 
a)
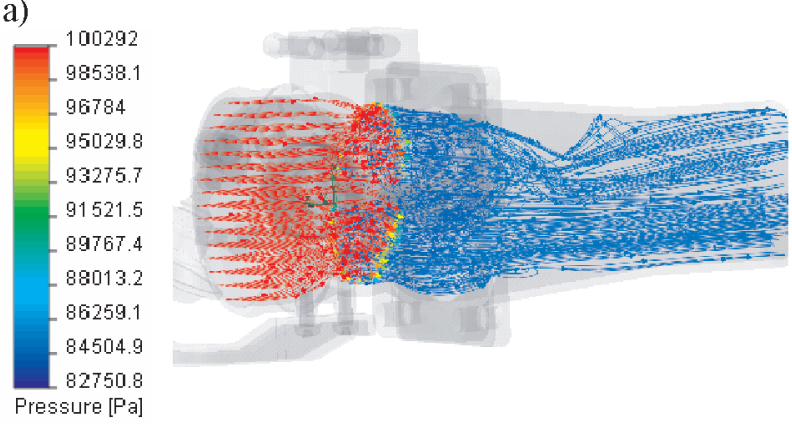

c)
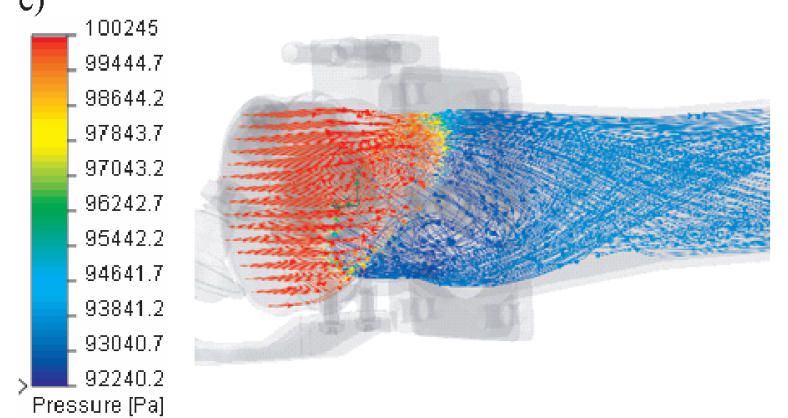

e)

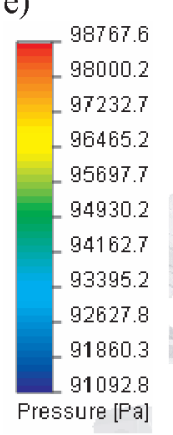

b)

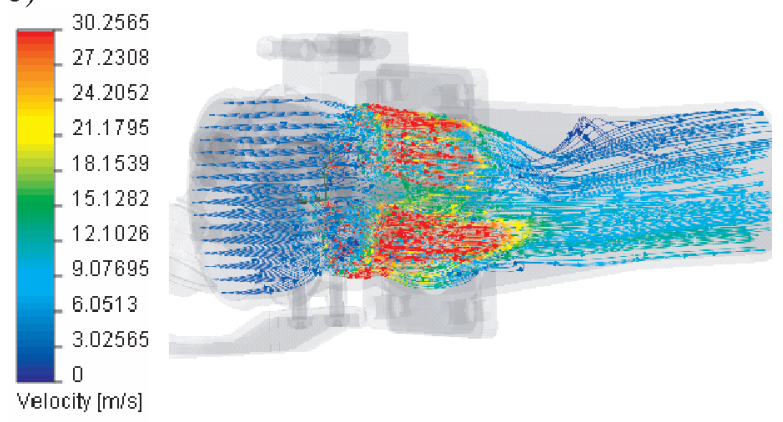

d)

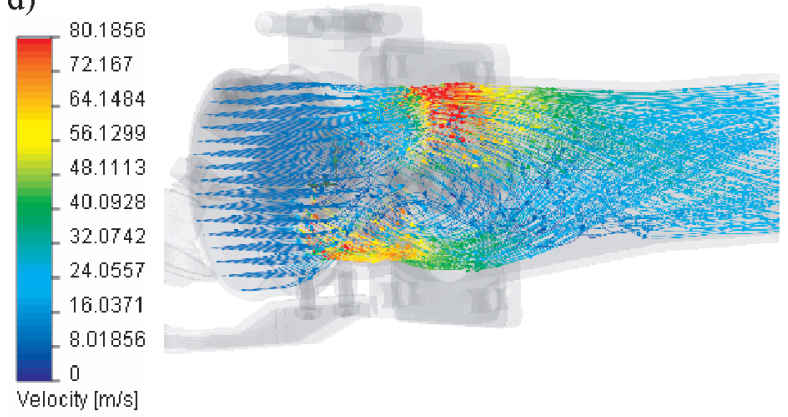

f)
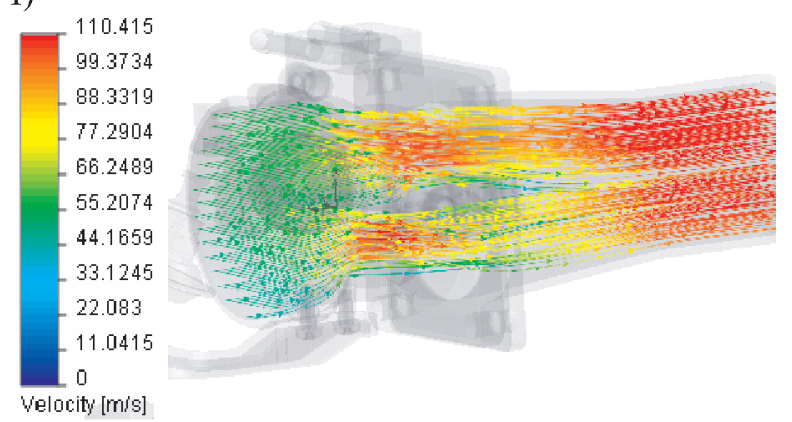

Fig. 6. Visualization of flow through the throttle profiled intake: $\mathrm{a}, \mathrm{c}, \mathrm{e}-$ pressure variations, $\mathrm{b}, \mathrm{d}, \mathrm{f}-\mathrm{flow}$ velocities; $\mathrm{a}$ and $\mathrm{b}-\alpha=10^{\circ}, \mathrm{t}=3.95 \mathrm{~s}$; $\mathrm{c}$ and $\mathrm{d}-\alpha=40^{\circ}, \mathrm{t}=1.32 \mathrm{~s}$; e and $\mathrm{f}-\alpha=90^{\circ}, \mathrm{t}=0.12 \mathrm{~s}$

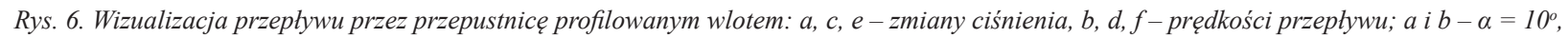
$t=3,95 \mathrm{~s}$; c id $-\alpha=40^{\circ}, t=1,32 \mathrm{~s}$; e if $-\alpha=90^{\circ}, t=0,12 \mathrm{~s}$

To open the throttle body $\alpha=40^{\circ}$ (Fig. $6 \mathrm{c}$ and d) the lower flow port is already uncovered. Nevertheless, the flow still mainly passes the upper surface opposite the profiling. The flow, like in the previous case, has scarce air stream swirl.

The impact of profiling vanished with the throttle body fully open (Fig. 6e and f). The current lines are almost parallel. The highest mass expenditure occurs in this case, around $0.85 \mathrm{~kg} / \mathrm{s}$, which is related to the largest passage diameter of all the throttle bodies investigated.

\section{Summary}

The experimental investigations on the measuring site, the computational analysis of flow parameters, combined with model investigations in the flow analysis programs enable obtainment of wide information on the properties of the object investigated. The investigations carried out so far that could only determine the quantita-

\section{Podsumowanie}

Badania doświadczalne na stanowisku pomiarowym wraz z obliczeniową identyfikacją parametrów przepływu w połączeniu z badaniami symulacyjnymi w programach do analiz przepływów pozwalają na uzyskanie wielu informacji na temat właściwości badanego obiektu. Prowadzone dotychczas badania, które potrafily określić jedynie charakter ilościowy przepływu, zakładając jego jednorodność, były niewystarczające. Badania symulacyjne stanowią uzupełnienie tych badań, niosąc ze sobą informacje o charakterze jakościowym.

Przeprowadzone badania symulacyjne, dla trzech różniących się konstrukcyjnie przepustnic, przy założeniu warunków brzegowych i początkowych odwzorowujących badania stanowiskowe, uzupełniły analizę o takie cechy, jak zawirowanie strugi, które w badaniach eksperymentalnych [1-3] było bardzo trudno przeanalizować. Badania przepustnicy z profilowanym wlotem potwierdzily progresywną zmianę przepustowości w zależności od stopnia otwarcia. Prze- 

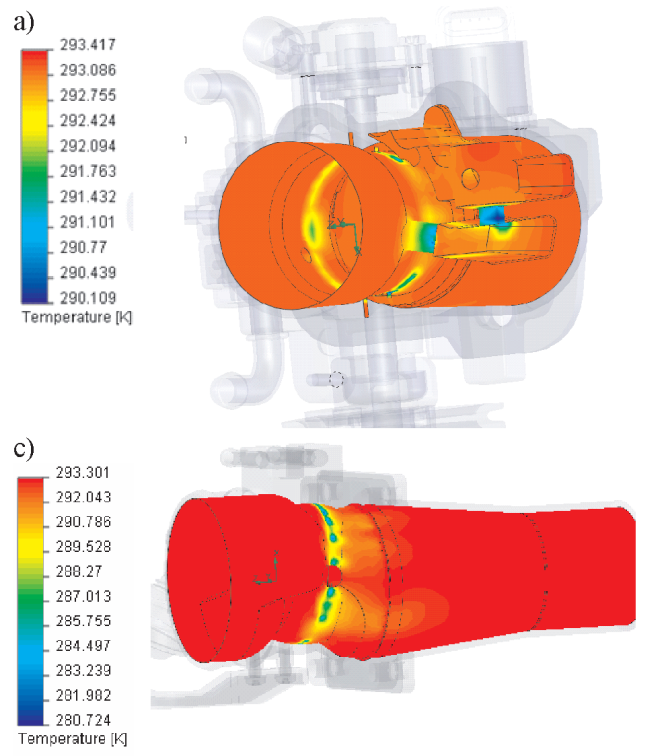

b)
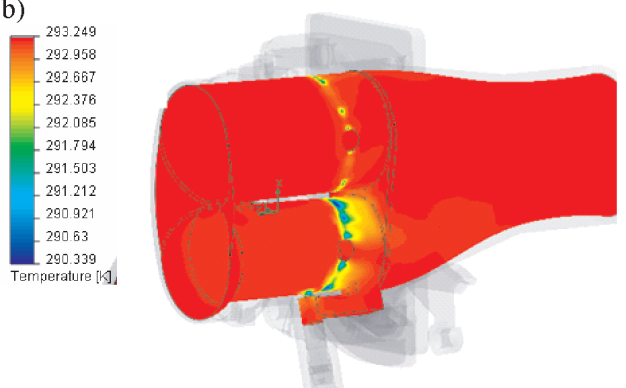

Fig. 7 Temperature distribution inside the passages of throttle bodies tested: $\mathrm{a}$ - classic throttle body, $\mathrm{b}$ - two stage throttle body, $\mathrm{c}$ - throttle body with profiled intake (edge and initial conditions, compliant with investigations at minimum openings)

Rys. 7 Rozklad temperatur wewnątrz przelotów badanych przepustnic: a - przepustnica klasyczna, $b$ - przepustnica podwójna, $c$ - przepustnica z profilowanym wlotem (warunki brzegowe i poczatkowe zgodne z badaniami przy otwarciach minimalnych) pustnica ta, niestety, nie sprawdzała się eksploatacyjnie (zanieczyszczenia powodowały problemy z otwieraniem) i w późniejszym czasie została zastąpiona klasycznym wlotem, lecz uzupełnionym o układ dźwigniowy sterowania listkiem.

W badaniach możliwa jest analiza, którą bardzo trudno jest przeprowadzić w rzeczywistości. Chodzi tu głównie o pomiary temperatury. W pewnych warunkach, przy dużej wilgotności powietrza i temperaturze tive nature of such flow, assuming its homogeneity, were insufficient. Simulation tests represent supplementation to the former, contributing qualitative information into them.

The simulation investigations made for three throttle bodies differing by structure, assuming the edge and initial conditions mapping the test stand investigations, complemented the analysis with such characteristics as: stream swirl that was very difficult to be analyzed in the experimental investigations [1-3]. The investigations on the throttle body with profiled intake confirmed the progressive change of throughput correlated with the opening grade. Unfortunately, the throttle body did not prove itself under operating conditions (the contaminants caused problems with opening) and was later replaced with classic intake, however, supplemented with lever flap control system.

The investigations enabled an analysis that is very difficult to be carried out in reality. This mainly concerns temperature measurement. Under certain conditions, with high air humidity and temperature oscillating around $0^{\circ} \mathrm{C}$, the throttle flaps often were frozen to the channel. Under virtual conditions (Fig. 7) a successful simulation was carried out to prove significant temperature drop for small openings around the flow ports.

The simulation tests can also be carried out on a physically non-existing object. The simulation provides the repeatability of tests under identical initial and edge conditions and also in widely variable parameter range or under critical conditions. These characteristics decide on fast development of simulation analyses in all the industrial sectors. They impact the reduction of time interval from the design to its performance and also the cost reduction of the designing stage.

Paper reviewed/Artykut recenzowany oscylującej wokół $0^{\circ} \mathrm{C}$ często listki przepustnicy przymarzały do kanału. Udało się w warunkach wirtualnych (rys. 7) przeprowadzić taką symulacje, wykazując dla małych otwarć znaczny spadek temperatury w okolicach szczelin przepływowych.

Badania symulacyjne można prowadzić także na obiekcie nieistniejącym fizycznie, a jedynie na stworzonym modelu opisującym cechy przyszłego rozwiązania. Symulacja zapewnia powtarzalność badań w tych samych warunkach początkowych i brzegowych, jak również w szeroko zmiennym zakresie parametrów, czy też w warunkach krytycznych. Są to cechy decydujące o szybkim rozwoju analiz symulacyjnych we wszystkich dziedzinach przemysłu. Mają wpływ na skrócenie czasu od chwili powstania projektu do jego wykonania, jak również na obniżenie kosztów związanych $\mathrm{z}$ etapem projektowania.

\section{Bibliography/Literatura}

[1] Czaban J.: Dobór kanałów dolotowych i ich wpływ na parametry silnika 135 R6TC. Silniki Spalinowe nr 1-2/1992.

[2] Hennig W., Staluszka T.: Studia nad doborem optymalnego kształtu kanału dolotowego silnika 359. Silniki Spalinowe nr 2/1973.

[3] Koliński K., Szczeciński S.: Próba oceny zawirowania ładunku w silniku ZI. AUTO-Technika Motoryzacyjna nr 3/1985.

[4] Rawski F., Szpica D.: Symulacyjne metody badań układów dolotowych tłokowych silników spalinowych. Przegląd Mechaniczny nr 2/2005.

[5] Szpica D.: Badanie przepustowości podzespołów przepustnic silników spalinowych o ZI. Silniki Spalinowe nr 2/2009.

Mr. Dariusz Szpica, DEng. - doctor in the Faculty of Mechanical Engineering at Bialystok University of Technology.

Dr inż. Dariusz Szpica - adiunkt na Wydziale Mechanicznym Politechniki Białostockiej. e-mail:dszpica@pb.bialystok.pl

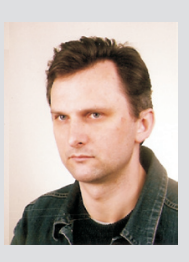

